\title{
Teknologi E-Booking Ruangan Untuk Kegiatan UKM (Unit Kegiatan Mahasiwa) STIKOM Bali
}

\author{
Agus Purwanto ${ }^{1)}$ Anggun Nugroho ${ }^{2)}$ \\ Program Studi Sistem Komputer \\ STMIK STIKOM Bali \\ agusp712@gmail.com ${ }^{1)}$ anggun.bali@gmail.com ${ }^{2)}$
}

\begin{abstract}
With the rapid development of technology, especially internet technology-based computing currently encourages the emergence of various technologies, especially internet-based applications. These applications are used on a small, medium or large scale and can be implemented on equipment that is often used by everyday humans for example smartphones. Many operating systems are currently circulating in the market and implemented in various types of smartphones, one of which is Android. The booking or booking process is a process that is carried out to order and a product or facility that will be used by the user, for example a flight ticket or hotel booking. STIKOM Bali is an institution engaged in education. In daily activities the activities carried out are academic or non-academic activities. Non-academic activities organized and creativity-based are usually carried out by the Student Activity Unit (UKM). In carrying out these activities, facilities from institutions where students usually use rooms are needed. E-booking application is a concept that can be a solution to handle orders to use room facilities at STIKOM Bali. By using internet technology, a web service and android based system was created for the ebooking system. The design of this system uses object-oriented models that are illustrated in the form of use case diagrams, class diagrams, activity diagrams, and sequence diagrams. The results of this study are an e-booking application that can be used to make room bookings by UKM management and managed by the unit and STIKOM Bali infrastructure.
\end{abstract}

Keywords: e-booking, room, UKM, STIKOM Bali

\begin{abstract}
ABSTRAK
Dengan pesatnya perkembangan teknologi, khususnya komputasi yang berbasis teknologi internet saat ini mendorong munculnya berbagai teknologi khusunya aplikasi-aplikasi yang berbasis internet. Aplikasiaplikasi tersebut dimanfaatkan dalam skala kecil, menengah ataupun besar dan dapat diimplementasikan pada peralatan-peralatan yang sering digunakan oleh manusia sehari-hari sebagai contoh smartphone. Banyak sistem operasi yang saat ini beredar dipasaran dan terimplementasi di berbagai macam smartphone, salah satunya adalah android. Proses booking atau pemesanan adalah sebuah proses yang dilakukan untuk memesdan suatu produk atau fasilitas yang akan digunakan oleh penggunanuya, sebagai contoh booking tiket pesawat atau hotel. STIKOM Bali merupakan sebuah lembaga yang bergerak di bidang pendidikan. Dalam kegiatan sehari-hari kegiatan yang dilakukan adalah kegiatan akademik ataupun non akademik. Kegiatan-kegiatan non akademik yang diselenggarakan dan berbasis kreatifitas biasanya dijalankan oleh Unit Kegiatan Mahasiswa (UKM). Dalam menjalankan kegiatan tersebut dibutuhkan fasilitas dari lembaga tempat bernaungnya mahasiswa yang biasanya menggunakan ruangan. Splikasi e-booking merupakan suatu konsep yang dapat menjadi solusi untuk menangani pemesanan untuk menggunakan fasilitas ruangan di STIKOM Bali. Dengan menggunakan teknologi internet maka dibuatlah sebuah sistem berbasis web service dan android untuk sistem $e$-booking. Perancangan dari sistem ini menggunakan model berorientasi objek yang tergambar dalam bentuk use case diagram, class diagram, activity diagram, dan sequence diagram Hasil dari penelitian ini adalah sebuah aplikasi e-booking yang dapat digunakan untuk melakukan pemesananpenggunaan ruangan oleh pengurus UKM dan dikelola oleh unit sarana dan prasarana STIKOM Bali.

Kata kunci : e-booking, ruangan, UKM, STIKOM Bali
\end{abstract}




\section{PENDAHULUAN}

Dengan pesatnya perkembangan teknologi, khususnya komputasi yang berbasis teknologi internet saat ini mendorong munculnya berbagai teknologi khusunya aplikasi-aplikasi yang berbasis internet. Aplikasi-aplikasi tersebut dimanfaatkan dalam skala kecil, menengah ataupun besar dan dapat diimplementasikan pada peralatan-peralatan yang sering digunakan oleh manusia sehari-hari sebagai contoh smartphone.

Banyak sistem operasi yang saat ini beredar dipasaran dan terimplementasi di berbagai macam smartphone, salah satunya adalah android. Proses booking atau pemesanan adalah sebuah proses yang dilakukan untuk memesdan suatu produk atau fasilitas yang akan digunakan oleh penggunanuya, sebagai contoh booking tiket pesawat atau hotel. STIKOM Bali merupakan sebuah lembaga yang bergerak di bidang pendidikan. Dalam kegiatan sehari-hari kegiatan yang dilakukan adalah kegiatan akademik ataupun non akademik Kegiatankegiatan non akademik yang diselenggarakan dan berbasis kreatifitas biasanya dijalankan oleh Unit Kegiatan Mahasiswa (UKM).

Dalam menjalankan kegiatan tersebut dibutuhkan fasilitas dari lembaga tempat bernaungnya mahasiswa yang biasanya menggunakan ruangan. Splikasi e-booking merupakan suatu konsep yang dapat menjadi solusi untuk menangani pemesanan untuk menggunakan fasilitas ruangan di STIKOM Bali. Dengan menggunakan teknologi internet maka dibuatlah sebuah sistem berbasis web service dan android untuk sistem e-booking. Perancangan dari sistem ini menggunakan model berorientasi objek yang tergambar dalam bentuk use case diagram, class diagram, activity diagram, dan sequence diagram Hasil dari penelitian ini adalah sebuah aplikasi $e$ booking yang dapat digunakan untuk melakukan pemesanan penggunaan ruangan oleh pengurus UKM dan dikelola oleh unit sarana dan prasarana STIKOM Bali.

\section{TINJAUAN PUSTAKA}

\section{State Of the Art}

Penelitian mengenai "Implementasi Sistem Informasi Pemesanan Pakaian Distro dengan Aplikasi Android", yang dipublikasikan oleh Yusuf Agung Pramono dari Universitas Muhammadiyah Surakarta. Pada penelitian ini dihasilkan sebuah implementasi sistem pemesanan pakaian pada distro Denim di kota
Yogyakarta dengan menggunakan sistem operasi Ginger dan trknologi pengembang eclipse dan MySQL sebagai databasenya.

Penelitian dengan judul "Aplikasi Penjualan Online Berbasis Android (Studi kasus : Toko Hoax Merch)", yang dipublikasikan pada jurnal Computech dan Bisnis oleh Marjito dan Gina Tesaria dari STMIK Mardira Indonesia. Pada penelitian ini dihasilkan sebuah aplikasi bebrbasis android untuk penjualan pada toko hoaxmerch, dimana sistem ini dapat menjadi m-commerce bagi pengusaha dalam penetrasi yang lebih luas dengan memanfaatkan teknologi informasi.

\section{Android}

Android adalah sebuah kumpulan perangkat lunak untuk perangkat mobile yang mencakup sistem operasi, middleware dan aplikasi utama mobile. Android memiliki empat karakteristik sebagai berikut:

- Terbuka. Android dibangun untuk benar-benar terbuka sehingga sebuah aplikasi dapat memanggil salah satu fungsi inti ponsel seperti membuat panggilan, mengirim pesan teks, menggunakan kamera, dan lain-lain. Android menggunakan sebuah mesin virtual yang dirancang khusus untuk mengoptimalkan sumber daya memori dan perangkat keras yang terdapat di dalam perangkat. Android merupakan open source, dapat secara bebas diperluas untuk memasukkan teknologi baru yang lebih maju pada saat teknologi tersebut muncul. Platform ini akan terus berkembang untuk membangun aplikasi mobile yang inovatif.

- Semua aplikasi dibuat sama. Android tidak memberikan perbedaan terhadap aplikasi utama dari telepon dan aplikasi pihak ketiga (third-party application). Semua aplikasi dapat dibangun untuk memiliki akses yang sama terhadap kemampuan sebuah telepon dalam menyediakan layanan dan aplikasi yang luas terhadap para pengguna.

- Memecahkan hambatan pada aplikasi. Android memecah hambatan untuk membangun aplikasi yang baru dan inovatif. Misalnya, pengembang dapat menggabungkan informasi yang diperoleh dari website dengan data pada ponsel seseorang seperti kontak 
pengguna, kalender, atau lokasi geografis.

- Pengembangan aplikasi yang cepat dan mudah. Android menyediakan akses yang sangat luas kepada pengguna untuk menggunakan library yang diperlukan dan tools yang dapat digunakan untuk membangun aplikasi yang semakin baik. Android memiliki sekumpulan tools yang dapat digunakan sehingga membantu para pengembang dalam meningkatkan produktivitas pada saat membangun aplikasi yang dibuat Google Inc. sepenuhnya membangun Android dan menjadikannya bersifat terbuka (open source) sehingga para pengembang dapat menggunakan Android tanpa mengeluarkan biaya untuk ijin dari Google dan dapat membangun Android tanpa adanya batasan-batasan. Android Software Development Kit (SDK) menyediakan alat dan Application Programming Interface (API) yang diperlukan untuk mulai mengembangkan aplikasi pada platform Android menggunakan bahasa pemrograman Java.

\section{Pemesanan}

Pemesanan adalah suatu aktivitas yang dilakukan oleh konsumen sebelum membeli. Untuk mewujudkan kepuasan konsumen maka perusahaan harus mempunyai sebuah sistem pemesanan yang baik. Dalam arti lain pemesanan adalah "proses, perbuatan, cara memesan (tempat,barang,dsb) kepada orang lain".

Pemesanan dalam arti umum adalah perjanjian pemesanan tempat antara 2 (dua) pihak atau lebih, perjanjian pemesanan tempat tersebut dapat berupa perjanjian atas pemesanan suatu ruangan, kamar, tempat duduk dan lainnya, pada waktu tertentu dan disertai dengan produk jasanya. Produk jasa yang dimaksud adalah jasa yang ditawarkan pada perjanjian pemesanan tempat tersebut, seperti pada perusahaan penerbangan atau perusahaan pelayaran adalah perpindahan manusia atau benda dari satu titik (kota) ke titik (kota) lainnya.

Dalam melakukan pemesanan hal yang harus diperhatikan adalah sebagai berikut :

- Product (produk), adalah segala sesuatu yang dapat ditawarkan ke pasar untuk diperhatikan, diperoleh dan digunakan atau dikonsumsi untuk dapat memenuhi kebutuhan dan keinginan meliputi barang fisik, jasa, orang, tempat, organisasi, gagasan dan ide.

- Price (harga), yaitu jumlah uang yang harus dibayar oleh pelanggan untuk memperoleh produk atau jasa untuk memperoleh satu buah produk dan hendaknya harga akan dapat terjangkau oleh konsumen.

- Place (saluran distribusi/tempat), termasuk aktivitas perusahaan untuk menyalurkan produk atau jasa tersedia bagi konsumen. Kemudahan akses terhadap jasa bagi para pelanggan. Tempat dimana produk serta merupakan keputusan distribusi menyangkut kemudahan akses terhadap jasa bagi para pelanggan. Tempat dimana produk tersedia dalam sejumlah saluran distribusi dan outlet yang memungkinkan konsumen dapat dengan mudah memperoleh suatu produk.

Promotion (promosi), berarti aktivitas yang meliputi berbagai metode yaitu iklan, promosi penjualan, mengkomunikasikan produk dan membujuk pelanggan. Menggambarkan berbagai macam cara yang ditempuh perusahaan dalam rangka menjual produk ke konsumen. Penjualan tatap muka dan hubungan masyarakat, mengkomunikasikan produk dan membujuk pelanggan, Menggambarkan berbagai macam cara yang ditempuh perusahaan dalam rangka menjual produk ke konsumen.

\section{ANALISIS DAN PEMBAHASAN}

Adapun perancangan sistem yang digunakan dalam penelitian ini adalah menggunakan UML (Unified Modelling Object), yang tujuannya untuk membuat desain konsep dari sistem yang akan dikembangkan. Diagram-diagram yang digunakan dalam melakukan analisis dan perancangan aplikasi ini adalah: Use case Diagram, Class Diagram, dan Design Interface

\section{Use Case Diagram}

Pada perancangan sistem ini digambarkan dalam 2 buah use case diagram yang tujuannya menjelaskan sebuah konsep dari sistem yang dibuat. Use case ini terdiri dai 3 pengguna yaitu :

a. Ka.Bag Sarpras, menggambarkan otorisasi yang dapat dilakukan oleh Ka.bag Sarpras adalah verifikasi user yang merequest agar dapat mengakses sistem ini. adapun user yang dapat diverifikasi adalah pengurus UKM 
yang me-request untuk dapat mengakses sistem ini. selain itu K.Bag Sarpras juga mempunyai kewenangan untuk mengelola data-data di sistem seperti data pengguna, data mobil, data jadwal pinjaman.

b. Staf Sarpras, adalah pengguna yang mempunyai otorisasi untuk melakukan pengelolaan pada sistem hanya sebatas pengelolaan data mobil dan data jadwal. Sehingga dengan adanya pengelolaan data yang dilakukan dapat digunakan oleh pengguna lainnya dalam mengakses data pada sistem.

c. Pengurus UKM, adalah pengguna yang mempunyai otorisasi pada sisem hanya sebatas transaksional saja yaitu transaksi pesan atau booking mobil.

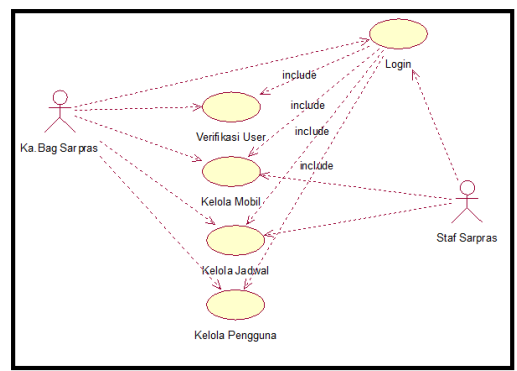

Gambar 1. Use case diagram untuk Ka.Bag Sarpras dan Staf Sarpras

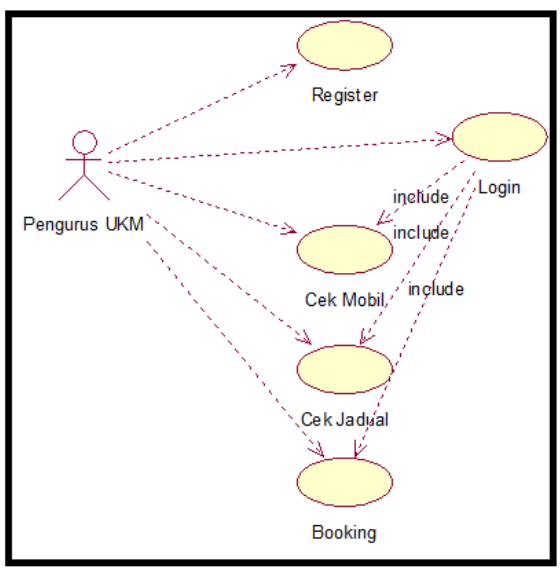

Gambar 2. Use case diagram untuk Pengurus UKM

Pada gambar 1 dan 2 dijelaskan pada sistem yang dibuat ini terdiri dari 3 user, dimana masing-masing user mempunyai kewenangan yang berbeda-beda seperti yang telah dijelaskan. Pada perancangan use case diagram menjelaskan secara umum gambaran dari sistem yang berjalan

\section{Class Diagram}

Pada gambar class diagram berikut menggambarkan hubungan antar class pada aplikasi. Class diagram tersebut menggambarkan objek-objek yang terdapat pada class, atribut, dan method yang dapat dilakukan pada saat merancang aplikasi $e$ booking ruangan.

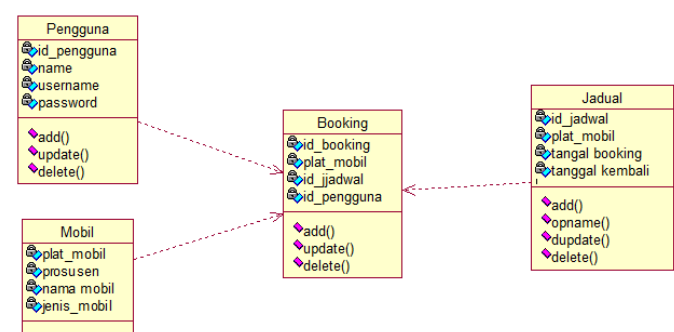

Gambar 3. Class diagram sistem e-booking ruangan

\section{Activity Diagram}

Pada activity diagram digambarkan mengenai alur aktivitas pada Aplikasi $e$ booking ruangan untuk UKM ini. Dalam activity diagram terjadi beberapa eksekusi yang menggambarkan proses paralel. Beberapa activity diagram yang tergambar pada aplikasi e-booking ruangan ini adalah sebagai berikut.

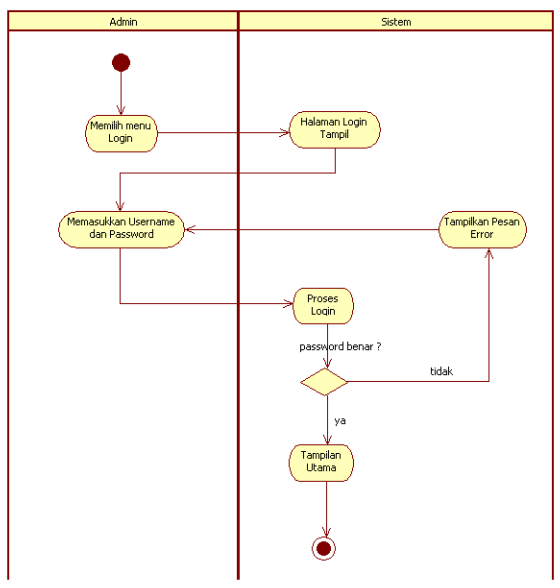

Gambar 4. Activity Diagram Login

Pada ganbar 4 diatas menjelaskan mengenai aktivitas awal pada saat pengguna ingin masuk ke sistem. Dalam activity diagram ini menggambarkan bagaimana aktivitas admin pada web server dan pengurus UKM pada android. Pada sistem ini terdapat 3 level pengguna yaitu admin, staff sarpras, dan pengurus UKM. 


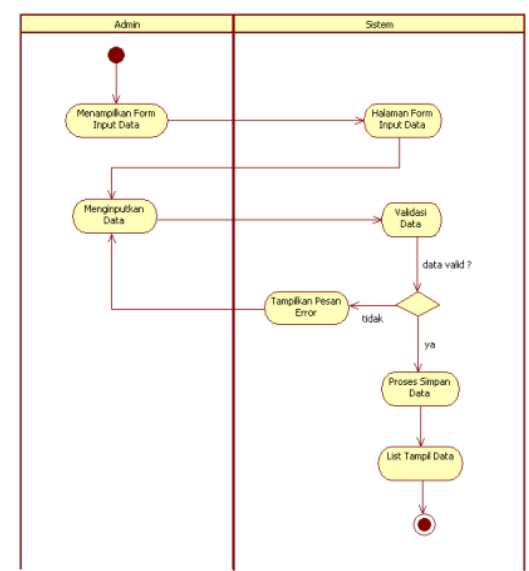

Gambar 5. Activity Diagram Tambah Data

Activity diagram tambah data pada gambar 5.2 menggambarkan aktifitas pengguna sebagai admin melakukan penambahan data ke sistem pada web server. Adapundata-data yang ditambahkan pada sistem diantaranya data-data master seperti data ruangan, data pengguna sistem, data waktu (hari, tanggal, jam), dan beberapa data lainnya yang diperlukan. Pada aktivitas tambah data diatas diterangkan jika pda saat melakukan penambahan ternyata data valid maka akan tersimpan, jika tidak akan muncul pesan error.

\subsection{Sequence Diagram}

Sequence Diagram menjelaskan urutan proses yang terjadi pada sistem dan hubungan antar objek dari urutan proses-proses tersebut. Urutan proses tersebut menggambarkan hubungan dari objek actor yang berada pada urutan paling kanan diawal, objek interface dari sistem, objek boundary dari sistem, hingga objek database. Dengan menggambarkan objek secara berurut dan hubungan proses antar objek, maka aan menjelaskan secara detail urutan aktifitas yang terjadi antar objek dalam suatu diagram sequence. Beberpa sequence diagram ini tergambar seperti berikut.

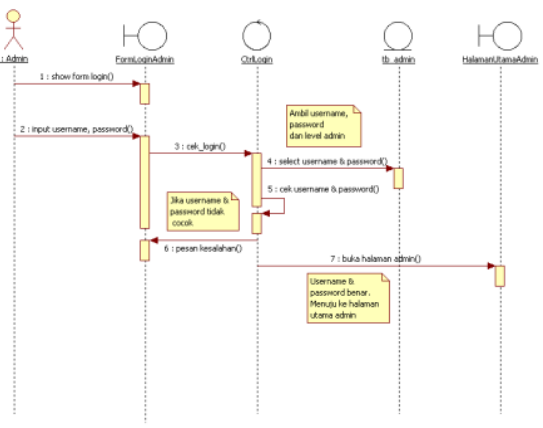

Gambar 6. Sequence Diagram Login

Sequence diagram pada gambar 6 menjelaskan proses login, dimana pada saat pengguna melakukan login dengan memasukkan username dan password, maka sistem akan mengecek ke database. Jika username dan password terdapat di database maka sistem akan mauk ke halaman pengguna baik sebagai admin ataupun pengurus UKM, namun jika salah atau tidak diketemukan didalam database maka sistem akan memberikan notifikasi dan kembali ke tampilan login kembali.

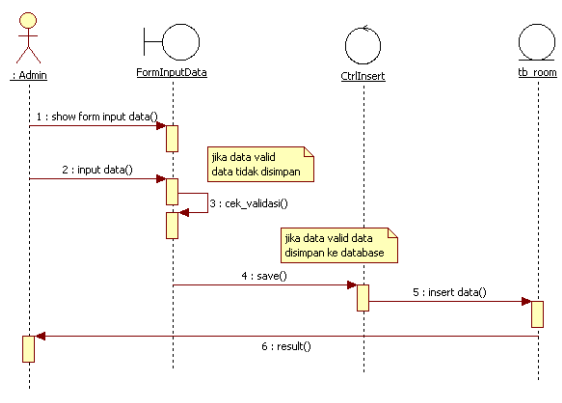

Gambar 7. Sequence Diagram Tambah Data

Pada sequence diagram diatas menjelaskan pada saat admin melakukan penambahan data pada sistem, maka data tersebut akan diinput melalui aplikasi dan disimpan pada database. 


\section{Tampilan Aplikasi}

Dari hasil perancangan yang telah dilakukan, menjadi sebuah konsep untuk menterjemahkan dalam bentuk aplikasi. Diaman aplikasi pada sistem $e$-booking ruangan untuk kegiatan UKM ini berbasis teknologi informasi dan komunikasi. Dalam sistem ini terdapat 2 aplikasi yaitu web server yang digunakan oleh admin untuk mengelola data dan staff sarpras untuk melakukan transaksi yang berhubungan dengan fasilitas yang ada di STIKOM Bali, khusunya fasilitas ruangan yang dapat digunakan untuk kegiatan akademis dan non akademis. Dengan adanya sistem ini, transaksi peminjaman ruangan dapat dilakukan secara mudah karana terdapat aplikasi yang menjadi tools untuk kegiatan peminjaman ruangan khusunya para UKM yang tersedia di STIKOM Bali, dan juga menunjang kegiatan non akademis yang menunjang kreatifitas para mahasiswa di lingkungan STIKOM Bali.

\section{Web serer}

Web server disini adalah sebuah aplikasi yang berbasis web yang digunakan oleh admin untuk melakukan pengelolaan data, seperti membuat data master ruangan, UKM, tanggal, dan waktu. Sedangkan staff sarpras dapat melakukan transaksi menginput peminjaman dari para pengurus UKM yang mengajukan peminjaman ruangan dengan cara melakukan booking pada aplikasi.berikut adalah tampilan awal yang sekaligus form login pada saat masuk kedalam web server.

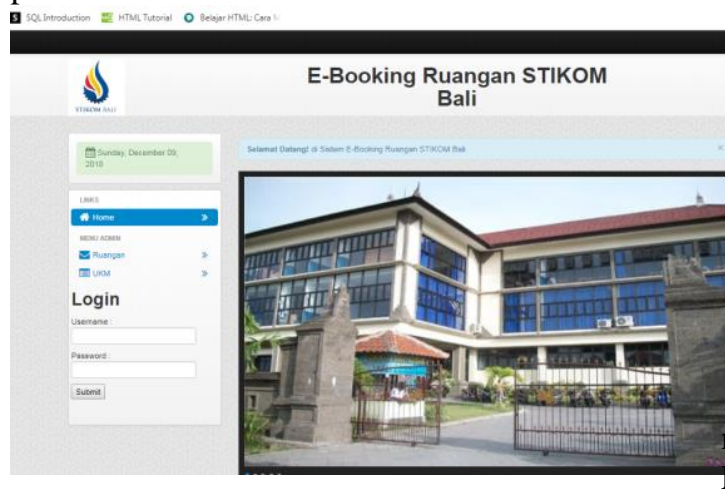

Gambar 8. Tampilan Menu Web Server

Pada saat menggunakan aplikasi ini admin dan staff sarpras melakukan login terlebih dahulu sebelum melakukan transaksi pada sistem. Pada saat login, jika pengguna sudah terdaftar maka akan dapat masuk kedalam menu-menu sesuai dengan hak akses apakah sebagai admin atau staf sarpras.
Pada gambar 8 menggambarkan tampilan pada saat admin masuk kedalam sistam aplikasi e-booking. Terdapat beberapa menu pada user admin yaitu beranda yang berisi slide show dari kampus dan beberapa ruangan di STIKOM Bali, menu Ruangan yang berisi data ruangan-ruangan yang ada di STKOM Bali yang dapat digunakan oleh UKM, dan menu UKM yang berisi data-data UKM yang terdaftar di STIKOM Bali.

\section{Aplikasi Android}

Pada aplikasi android ini dikhusukan untuk pengguna dengan hak akses sebagai pengurus UKM. Pada saat mengakses aplikasi maka pengguna harus memasukkan username dan password terlebih dahulu yang telah didaftarkan oleh admin pada web server. Jika ditemukan username dan password di database maka akan dapat masuk ke halaman menu di aplikasi android.

Sebelum melakukan transaksi booking ruangan, pengurus UKM melakukan login kedalam aplikasi jika sudah mendaftarkan dan disetujui oleh staff sarpras. Berikut pada gambar 5.10 adalah tampilan login di aplikasi android.

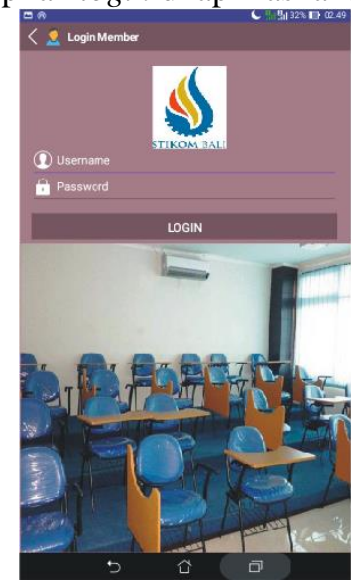

Gambar 9. Tampilan Menu Login Pada Aplikasi Android

Tampilan utama terdiri dari 4 buah nenu dimana di antaranya adalah Menu Daftar, Login, Ruangan, dan Informasi booking. Pada menu daftar pengurus UKM dapat melakukan pendaftaran sebagai pengguna sistem dan memilih dari UKM apa, lalu staff sarpras akan menyetujui atau menolak pendaftaran tersebut. Pada menu Login pengguna dapat login sesuai data yang sudah didaftarkan sebelumnya. Untuk menu ruangan akan terdapat daftar ruangan beserta gambar ruangan dan status ruangan, jadi pada menu ini pengurus UKM dapat melakukan booking dengan memilih ruangan, mengisi tanggal dan hari serta jam 
pemakaian dan akan muncul status apakah sudah terbooking atau masih free. Setelah itu staff sarpras dapat melakukan persetujuan/menolak booking dari pengurus UKM. Berikut adalah tampilan dari halaman menu utama pada aplikasi android.

\section{SIMPULAN}

Beberapa hal yang dapat disimpulkan dari penelitian ini adalah sebagai berikut:Telah dilakukan analisis dan dituangkan dalam perancangan sebuah aplikasi e-booking ruangan untuk kegiatan UKM di STIKOM Bali. Perancangan yang dilakukan menggunakan pendekatan object oriented dengan menggunakan use case dan class diagram Telah dihasilkan sebuah pengembangan aplikasi untuk sistem e-booking ruangan berbasis mobile.

\section{Daftar Pustaka}

[1] Kurniawati, Ria., dan Manuputty, A.D. 2013. "Analisis Kualitas Layanan Teknologi Informasi dengan Menggunakan Framework Information Technology Infrastructure Library V.3 (ITIL V.3) Domain Service Transition (Studi Kasus pada Costumer Service Area Telkom Salatiga)". Skripsi, Salatiga : Jurusan Sistem Informasi Universitas Kristen Satya Wacana.

[2] Junginger, Aprila. et al. 2016. "Analisis Kualitas Layanan TI pada Aplikasi SliMs Menggunakan Framework ITIL V.3 Domain Service Operation (Studi Kasus : Kantor Perpustakaan dan Arsip Daerah Kota Salatiga).

[3] IT Service Management Forum, An Introductory Overview of ITIL V.3.

[4] Cahyaningtyas, AR. Anggun. et al. 2012. "Audit Sistem Informasi dengan ITIL Version 3 Sub Domain Service Desk, Incident Management, dan Problem Management di Bidang Keuangan Dishubkombudpar Kota Salatiga”. Skripsi, Salatiga : Jurusan Sistem Informasi Universitas Kristen Sayta Wacana.

[5] Caroline, Yoan., dan Manuputty, A.D. 2015. "Analisis Kualitas Layanan TI Menggunakan ITIL V.3 (Studi Kasus: Keuangan Group PT. Pura Barutama”. Skripsi, Salatiga : Universitas Kristen Satya Wacana. 